\title{
Congenital syphilis in Mexico. Analysis of national and international standards from the perspective of laboratory diagnosis
}

\author{
Antonia Herrera-Ortiz, Hugo López-Gatell, Santa García-Cisneros, María Alejandra Cortés-Ortiz, \\ María Olamendi-Portugal, Jennifer Hegewisch-Taylor, and Miguel Ángel Sánchez-Alemán* \\ Centro de Investigación Sobre Enfermedades Infecciosas, Instituto Nacional de Salud Pública, Cuernavaca, Morelos, Mexico
}

\begin{abstract}
Introduction: Congenital syphilis continues to be a public health problem in Mexico. Objective: To assess the similaritiesand differences between national standards, guidelines and international documents related to the detection of syphilis in pregnant women and congenital syphilis. Method: Two algorithms were developed based on the standard of female care during pregnancy and on the standard for prevention and control of sexually transmitted infections. Based on the Centers for Diselase Control (CDC) guidelines, algorithms were developed for syphilis during pregnancy, syphilis in the newborn and sexual contacts. Results: The standard for pregnancy mentions that syphilis testing should be carried out in every pregnant woman on he? first contact or at delivery, without diagnostic tests being specified. The Official Mexican Standard (NOM) on sexually transmitted infections mentions the traditional algorithm for syphilis detection, treatment follow-up, coinfection with human immunodefieiency virus and congenital syphilis criteria. The CDC recommend reverse algorithm, antibody titer, treatment and follow-up as part of diagnosis. Conclusions: The elimination of mother-to-child transmission of syphilis requires NOMs updating and homogenizing, as well as the study of stillbirths and neonates born to mothers with syphilis.
\end{abstract}

KEY WORDS: Congenital syphilis. Serodiagnosis of syphilis. Infectious complications of pregnancy. Clinical practice guidelines.

\section{Introduction}

Treponema pallidum is a bacterium that can cross the placenta, and thus a pregnant woman with syphilis can present with spontaneous abortion, fetal death or premature birth, and the neonate, congenital syphilis (CS). CS is a severe form of the condition that can occur at any clinical stage of maternal disease, and it also depends on the week of pregnancy. ${ }^{1,2}$

In Latin America and the Caribbean, maternal syphilis and CS constitute a serious public health problem: the prevalence of syphilis in pregnant women ranges from 0.1 to $7.0 \%$; 1.7 cases of CS per 1000 live births were estimated in 2015. ${ }^{3}$ For Mexico, the number of CS reported cases increased from 43 in 2013 to 121 in $2017 .{ }^{4}$ A national survey in Mexico found $6.6 \%$ of antibodies against Treponema pallidum in women with a history of stillbirths and $2.6 \%$ of antibodies in wermen without stillbirths, which suggests an association between Treponema pallidum and miscarriage. ${ }^{5}$ Several studies in pregnant women in Mexico have detected a prevalence of syphilis ranging between 0.26 and $2.3 \%$. $^{6-9}$

In 1994, the Pan American Health Organization made the first call for the elimination of CS in the Americas; in 2009, that organization and othe United Nations Children's Fund launched an initiative to eliminate mother-to-child transmission (EMTC.T) of human immunodeficiency virus (HIV) and CS in Latin America and the Caribbean; EMTCT-plus was launched in 2017, which adds maternal and child
Correspondence:

*Miguel Ángel Sánchez-Alemán

E-mail: msanchez@insp.mx
Date of reception: 23-10-2018

Date of acceptance: 19-03-2019

DOI: 10.24875/GMM.M20000328
Gac Med Mex. 2019;155:430̈438

Contents available at PubMed

www.gacetamedicademexico.com

0016-3813/@ 2019 Academia Nacional de Medicina de México, A.C.. Published by Permanyer. This is an open access article under the CC BY-NG-ND license (http://creativecommons.org/licenses/by-nc-nd/4.0/). 
elimination of hepatitis B and Chagas disease..$^{10-11}$ The initiative sought to reduce the incidence of CS to 0.5 cases or less (including stillbirths) per 1000 live births for 2015; this goal has been met in 20 nations, out of which Cuba was the first to receive validation from the World Health Organization. Mexico is one of the countries that report progress towards elimination, although it has not reached the goal. ${ }^{12}$

The Pan American Health Organization considers implementing rapid diagnostic tests, offering immediate treatment and involving the sex partners of patients with syphilis, as crucial measures to end mother-tochild transmission by $2030 .{ }^{12}$ There are recommendations in international documents and in various official Mexican standards, which provide guidance on procedures related to the prevention, detection and treatment of syphilis in pregnant women. The purpose of this study is to present an analysis of national and international standards, focused on the laboratory diagnosis of syphilis in pregnant women as the first step in the prevention of vertical transmission of syphilis in Mexico.

\section{Method}

In the project Longitudinal analysis of determinants and design of a comprehensive strategy for the prevention of vertical transmission of HIV and congenital syphilis in Mexico, international and national documents were reviewed in order to identify the interventions involved in the diagnosis of maternal syphilis as a measure of CS prevention. A working team, of at least three people for each document, read each one of the official Mexican standards (NOM - Norma Oficial Mexicana). Two standards were initially reviewed, NOM-007-SSA2-2016, for the care of the woman during pregnancy, delivery and puerperium and of the newborn, ${ }^{13}$ and NOM-039-SSA2-2014, for the prevention and control of sexually transmitted infections. ${ }^{14}$ These documents refer to additional standards, which were reviewed and out of which six were selected, for in-depth analysis. The selection criteria were that they should contain one of the following terms: syphilis, treponema, sexually transmitted infection (STI), sexually transmitted disease (STD) or HIV. ${ }^{15-20}$ From the review of the first two standards, two schemes were generated, where the activities to be performed are presented.

Subsequently, the master catalog of clinical practice guidelines (CPG), issued by the Ministry of Health, was reviewed, where two CPGs were found and reviewed: Sexually transmitted diseases in adolescents and adults that cause genital ulcers: herpes, syphilis, chancroid, venereal lymphogranuloma and ingüinal granuloma; ${ }^{21}$ and Diagnosis, treatment and followt-up of congenital syphilis at primary and secondary care. ${ }^{22}$ Documents of the World Health Organization and the Pan American Health Organization were also sought; only strategic documents, without operational elements for the detection of syphilis by laboratory tests, were identified. The search was broadened to inctude the Centers for Disease Control and Prevention (CEDC) of the United States; we found a document thatestablishes the procedures related to the prevention, diagnosis and treatment of syphilis in pregnant women and CS, which was used as an international referen̈ce. Three activity schemes were generated, correspönding to the diagnosis of syphilis during pregnancy- $\mathrm{di}-$ agnosis of syphilis in newborns of seropositive mothers and diagnosis of sexual contacts of people diagnosed with syphilis. ${ }^{23}$

\section{Results}

Eight official Mexican standards were analyzed; Table 1 describes the key aspects related to syphilis. NOM-007-SSA2-2016 algorithm for care during pregnancy (Fig. 1) clearly states that syphilis testing should be performed in all pregnant women at first contact with the health sector or at delivery, if that was their first contact. This standard does not specify the Eype of tests for the detection of syphilis, or the treatment and follow-up of the newborn or contacts. NOM-039SSA2-2014 on STIs (Fig. 2) refers that syphilis diagnosis depends on its clinical stage, and indicates the type of tests to be performed, as well as the pectodicity of treatment and HIV co-infection follow-up.Actions for pregnant women with syphilis are established and the need for presumptive and confirmatory tests at each trimester, even after the delivery, is indicated. Treatment is established according to the clinical stage, and the criteria to rule out CS are listed, as well as the follow-up for presumptive or confirmed cases.

The CPG Sexually-transmitted diseases in adolescents and adults that produce genital ulcers: herpes, syphilis, chancroid, venereal lymphogranuloma and inguinal granuloma lacks a specific section for pregnant women; it mentions evidence and recommendations for the diagnosis, management and treatment of ulcerative STIs in adolescents and adults. It indicates that every pregnant woman should be screened and that a Venereal Disease Research Laboratory (VDRL) test with an 
Table 1. List of official Mexican standards associated with the care of pregnancy and syphilis

Standard
NOM-007-SSA2-2016,
for the care of the woman
during pregnancy, delivery
and puerperium and of the
newborn

NOM-010-SSA2-2018, for the prevention and control of human immunodeficiency virus infection
Purpose of the standard

Establishing minimum criteria for medical care of the woman during pregnancy, delivery and normal puerperium and for the newly born person.

Establishing and updating the methods, principles and operational criteria of activities related to prevention and control, which include HIV infection detection, timely diagnosis, care and medical treatment.

NOM-017-SSA2-2012, for epidemiological surveillance

NOM-034-SSA2-2013. For the prevention and control of birth defects

NOM-039-SSA2-2014, for the prevention and control of sexually transmitted infections

NOM-046-SSA2-2005, family and sexual violence and violence against women. Criteria for prevention and care

NOM-253-SSA1-2012, for the use of human blood and its components for therapeutic purposes
Establishing guidelines and operating procedures, as well as criteria for the application of epidemiological surveillance in diseases, events and emergency situations that affect or put human health at risk.

Establishing criteria and specifications for the prevention, diagnosis, treatment and control of birth defects. The main preventable defects or those susceptible to early diagnosis are included, as well as prevention and control measures that may have an epidemiological impact on perinatal morbidity and mortality rates.

Establishing and standardizing the procedures and operating criteria for the prevention and control of sexually transmitted infections.

Establishing criteria for the detection, prevention, medical care and guidance provided to users of health services in general, and in particular to those who are involved in situations of family or sexual violence, as well as for the report of cases.

Establishing activities, criteria, strategies and operational techniques with regard to the use of human blood and its components for therapeutic purposes.
Content regarding syphilis

It seeks to prevent syphilis and HIV perinatal transmission, through timely detection and treatment? establishes that laboratory testing should be performed to detect syphilis in the pregnant woman and prevent CS (5.2.1.14.7; 5.2.1.14.8)

It establishes that childbearing age or pregnant wome and their sex partners should be offered HIV and syphilis screening (5.13-5.15).

HIV and syphilis screening in pregnant women shoute be carried out at least twice during pregnancy: an initia test within the first 12 weeks of pregnancy or at first contact and a second test prior to delivery (6.3.4.2).

It establishes CS as an immediately reportable infection (7.12), acquired and congenital syphilis as subject of weekly report (7.14.5.4). CS-related cases-o deaths are subject to epidemiological case study (89) CS requires laboratory confirmation (12.6.3.3).

CS is defined as that infection caused by Treponema pallidum that is transmitted from the mother to the chill via trans-placental circulation. The use of VDRL or rapid tests for prenatal diagnosis and neonatal syphitis screening, and FTA-ABS use in postnatal follow-up is established (8.2.1.)

It establishes the guidelines for the detection (diagnof methods), treatment and monitoring of syphilis during pregnancy (7.4.5), as well as the criteria for the diagnosis of CS in newborns (7.4.5.6).

In case of abuse in pregnant women, assess, among others, recurrent genital infections during pregnancy, with the support of laboratory and imaging exams and special studies (6.2.1.6.)

Syphilis and other transfusion-transmitted diseases are grounds for deferral of blood or blood components donation for up to 12 months (6.10.6.3). Guidelines for the diagnosis of Treponema pallidum, as well as tests that can be used for screening (VDRL/RPR/IC/IEA) abid confirmation (HA/FTA-ABS/IF/IMM) (9.4.9)

$\mathrm{CS}=$ congenital syphilis, HIV = human immunodeficiency virus, $\mathrm{STI}=$ sexually transmitted infections, IC = immunochromatography, IEA = immunoenzymatic assay, $\mathrm{HA}=$ hemagglutination, FTA-ABS = fluorescent treponemal antibody absorbed test, IF = immunofluorescence, IMM = treponemal immobilization.

1:8 titer is suggestive of positivity for syphilis; it refers to laboratory tests for the detection of syphilis in symptomatic individuals. The CPG Diagnosis, treatment and follow-up of congenital syphilis at primary and secondary care defines a probable, confirmed and annulled case of congenital syphilis, as well as syphilis-associated death. It specifies the actions for diagnosis, management and treatment of $\mathrm{CS}$; the guidelines regarding the newborn are detailed; however, they are restricted to cases of CS and do not address the pregnant woman, and thus their application has no effect on the prevention of syphilis vertical transmission.
The Sexually Transmitted Diseases Treatment Guidelines 2015, from the CDC, establish guidelines for the detection, treatment and follow-up of STIS; in the syphilis during pregnancy section, the guidelines for diagnosis during pregnancy, the premises for the follow-up of the newborn and the guidelines for the follow-up of contacts stand out. The use of the revērse algorithm is recommended (Fig. 3), which starts with a treponemal test, followed by a non-treponemal test and, if necessary, a confirmatory treponemal test. In äddition, antibody titers, previous treatments and the feasibility of follow-up of the pregnant woman are considered. 


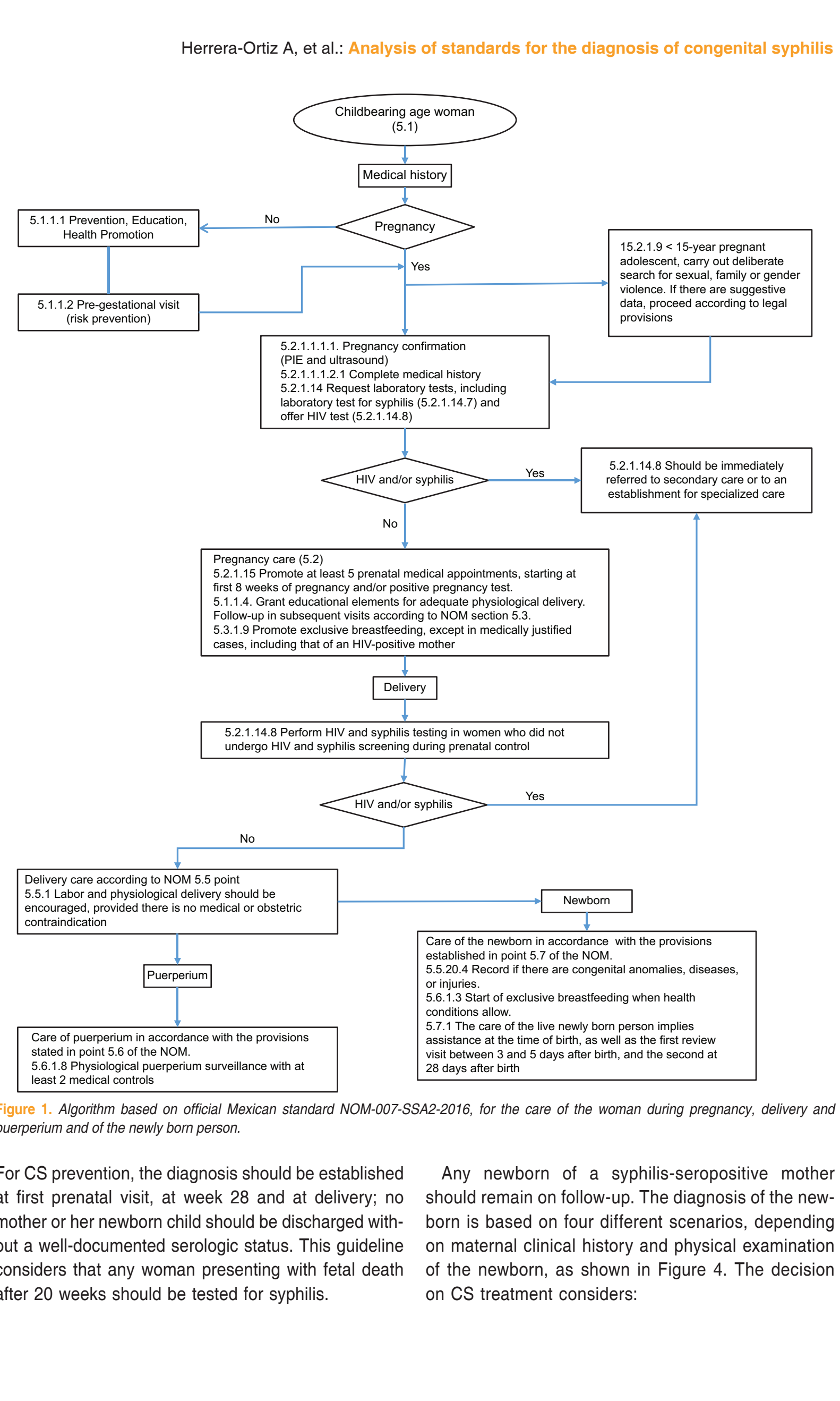




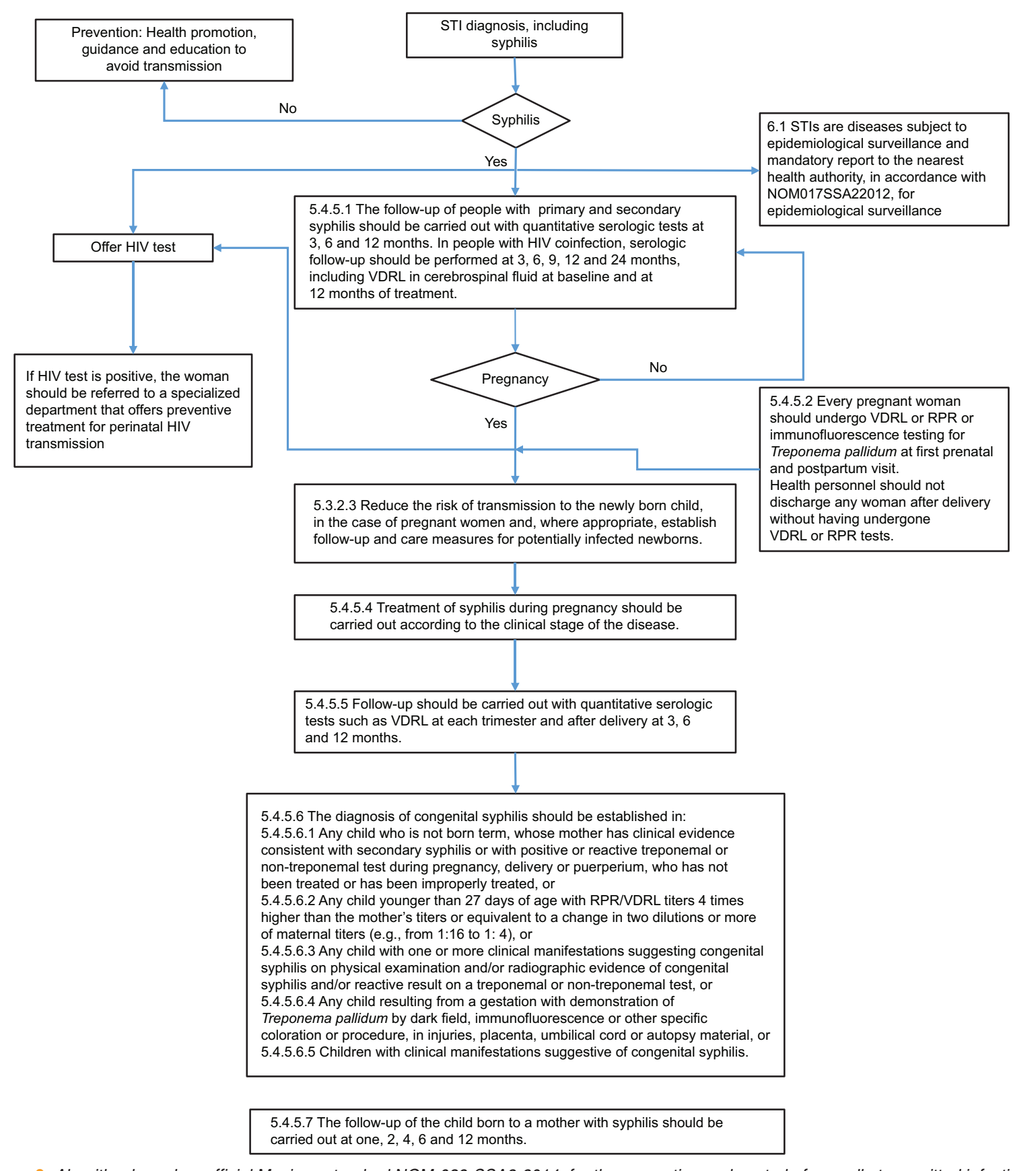

Figure 2. Algorithm based on official Mexican standard NOM-039-SSA2-2014, for the prevention and control of sexually-transmitted infections.

- Identification of syphilis in the mother.

- Proper treatment of the mother.

- Clinical, radiological or laboratory evidence of syphilis in the newborn.

- Comparison of antibody titers, maternal versus neonatal.

It is important to underscore that this guideline does not recommend the use of treponemal serologic tests for the newborn, and it indicates that there are no reliable IgM tests. Finally, with regard to the follow-up of contacts, it is established that sexual contacts of persons under treatment should be confidentially reported. The follow-up differs depending on the stage of the disease and the period between sexual confact and syphilis diagnosis. The algorithm considers the feasibility of follow-up and the use of serologic tests (Fig. 5).

\section{Discussion}

To achieve the elimination of CS it is essentiat to have an updated regulatory framework, focused on 


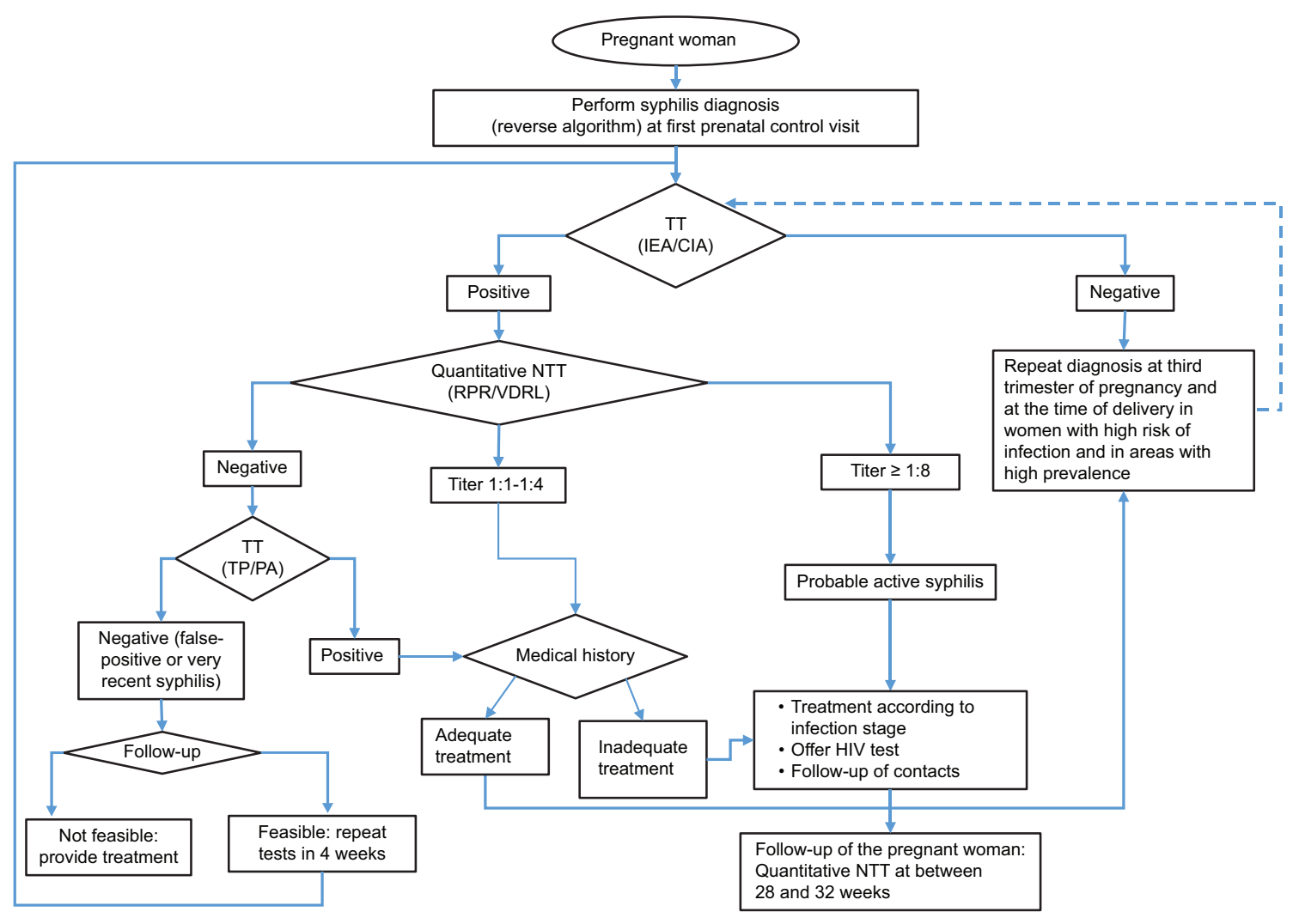

Figure 3. Algorithm relative to pregnant women based on Sexually Transmitted Diseases Treatment Guidelines, 2015, Centers for Disease Control and Prevention. $T T=$ treponemal test, IEA = immunoenzymatic assay, CIA = chemiluminescent immunoassay, NTT = non-treponemal test, $T P-P A=T$. pallidum passive particle agglutination assay.

the mother-child binomial, similar to that which Mexico has for HIV, as appreciated in the CPG Prevention, diagnosis and treatment in the mother-child binomial with HIV infection. ${ }^{24}$ According to the reviewed information, the official Mexican standards and the CPGs do not appear to be aimed at preventing mother-tochild syphilis transmission, but rather at a series of guidelines to guarantee minimum quality standards in the country. There is a lack of documents focused exclusively and specifically on the prevention of CS or in conjunction with HIV/Chagas/hepatitis B prevention, which should comprehensively consider the mother, the newborn and sexual contacts, and emphasize the follow-up of cases, in order to avoid vertical and sexual transmission.

At the state level, the document Guidelines for the diagnosis and management of syphilis in pregnancy and prevention of congenital syphilis, of the government of Sonora, ${ }^{25}$ which considers a comprehensive approach to the mother-child binomial stands out; however, it is based on the 2006 version of the CDC guidelines for STIs and requires the support of updated official Mexican standards.

Syphilis timely diagnosis in a pregnant woman is the first step for the prevention of CS; however, international recommendations suggest additional time points to detect syphilis, not only during the first but also during the third trimester and at the time of delivery. ${ }^{23}$ Regarding the type of tests, NOM-039SSA2-2014 on STIS mentions that laboratory tests should be performed according to the stage of the disease, by dark-field microscopy or immunofluorescence in primary syphilis and by VDRL, Rapid Plasma Reagin (RPR) test and FTA-ABS in secondary syphilis. Diagnosis based on clinical manifestations overlooks asymptomatic cases, which constitute the majority, and which can also cause SC. ${ }^{2}$ These guidelines for the diagnosis of syphilis differ from other official Mexican standards; there are variations regarding the timing for diagnosis and the suggested techniques for performing it. In NOM-034-SSA2-2013 on birth defects, VDRL is mentioned as prenatal screening as well as rapid tests, and for postnatal follow-up, ETAABS. Finally, in NOM-253-SSA1-2012 on the use of human blood, specifically in the section on blood transfusion, various screening tests (VDRL, RPR, enzymatic and chromatographic immunoassays) and confirmatory tests (hemagglutination, fluorescent äntibody absorption, indirect immunofluorescence and treponemal immobilization) are mentioned. 


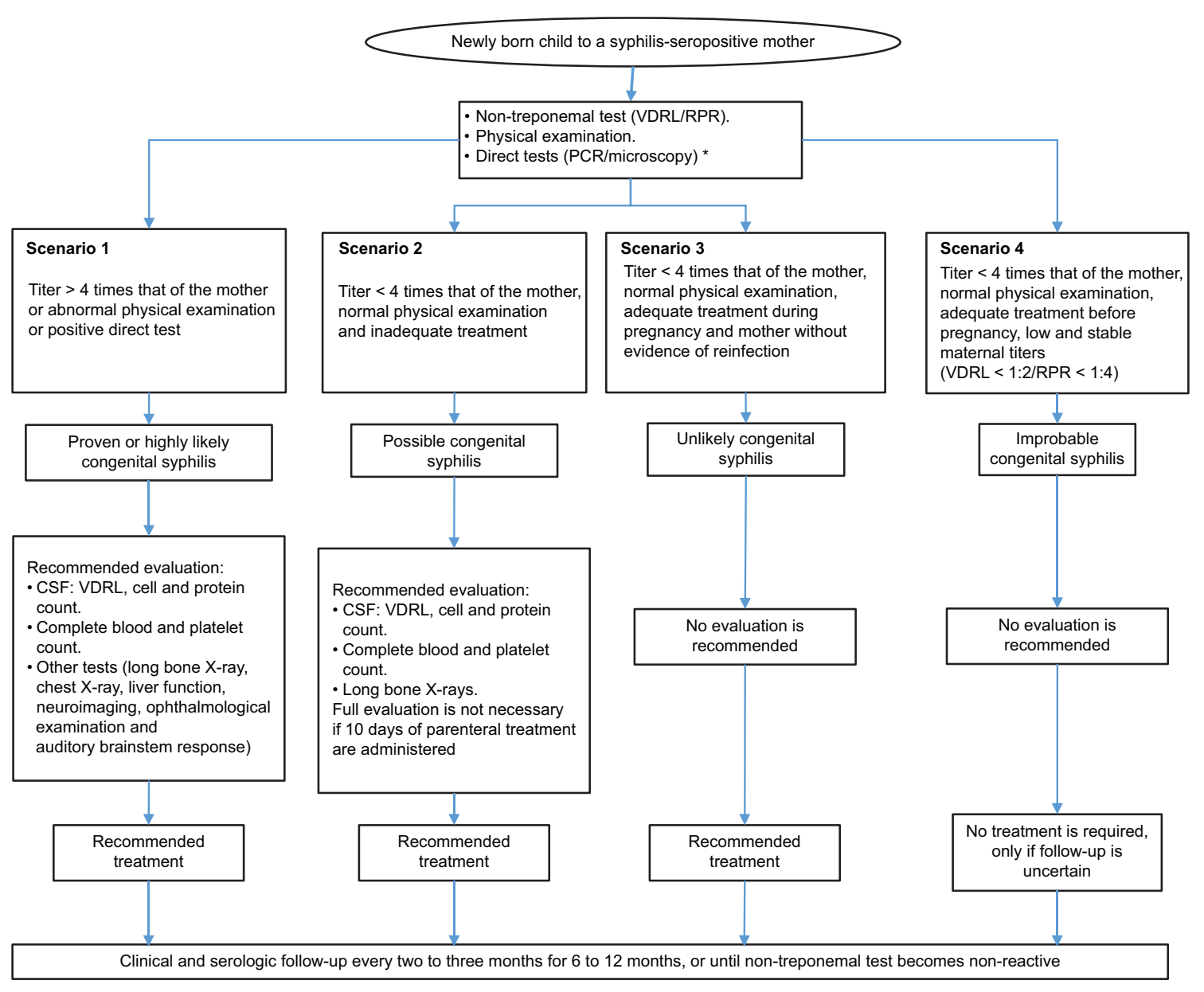

Figure 4. Algorithm relative to the newborn. Adapted from Sexually Transmitted Diseases Treatment Guidelines, 2015, Centers for Disease Control and Prevention.

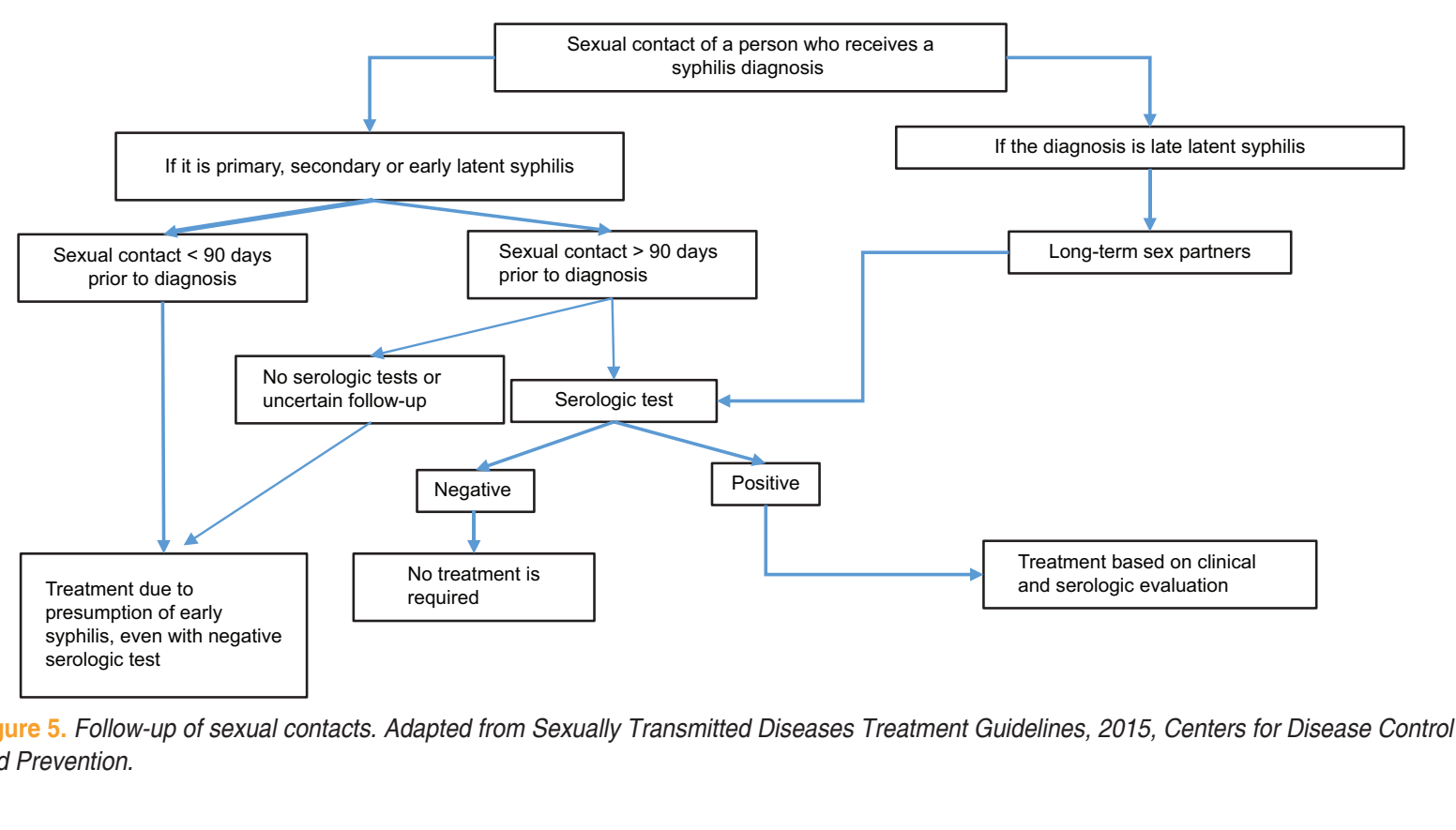

With regard to diagnostic methods, some direct tests mentioned in the official Mexican standards are

in disuse. In 2014, a study was conducted in 69 laboratories and only two of them performed dark-field 
microscopy tests. ${ }^{26}$ In NOM-253-SSA1-2012, on the use of human blood, the mention of the treponemal immobilization method stands out, which the World Health Organization recommended in 1956 and that currently is not used. ${ }^{27}$ Conversely, there are other direct tests that are not mentioned in the official Mexican standards, mainly molecular tests, which are increasingly being widely used. ${ }^{28}$ Regarding confirmatory tests, NOM-253-SSA1-2012 only mentions FTA-ABS, traditionally the gold standard; however, currently there are other types of confirmatory tests such as MHA-TP (microhemagglutination assays), TP-PA (passive particle agglutination assay) and TP-HA (hemagglutination assay), with higher acceptance due to the cost, time, training and lack of requirement of sophisticated equipment. ${ }^{29}$

According to the results of the quality control program for syphilis serology, 110 laboratories reported TP-PA/TP-HA tests and only 52 reported FTA-ABS assays. ${ }^{30}$ On the other hand, it is necessary to consider the reverse algorithm, starting with a treponemal test; subsequently, titration with non-treponemal tests and, if necessary, confirmation with a second treponemal test. ${ }^{23,31}$

The World Health Organization has highlighted the use of rapid tests, widely used for HIV detection: they do not require a laboratory, training and interpretation are simple and results are available in $\mathbf{3 0}$ minutes at the most. ${ }^{32}$ In the official Mexican standards related to pregnancy and STIs, their use for the detection of syphilis is not considered; however, in the standards for congenital diseases, rapid tests for syphilis are mentioned, which exemplifies the need to harmonize the official Mexican standards related to CS. There are also dual tests, immunochromatographic strips that simultaneously detect two infectious agents, such as HIV and syphilis; the usefulness, sensitivity and specificity of this type of evidence is still under study. ${ }^{33}$

Another important aspect in the prevention of congenital transmission is follow-up. NOM-039-SSA2-2014 indicates that syphilis-positive women should be followed up with quantitative tests at three, six and 12 months, and newborns of mothers with a history of syphilis at two, four, six and 12 months. International guidelines consider verifying if the woman was on previous treatment against syphilis, in addition to taking into account the search for the woman's contacts based on the stage of syphilis, in order to offer them the syphilis test and treatment. ${ }^{28}$ The official Mexican standards mention that follow-up should be carried out, but without the necessary emphasis to help stop transmission. A further point regarding follow-up is the verification of CS in the stillbirths of women who had syphilis during pregnancy; it is probable that no all cases of CS are being reported in many countries, since definitions of CS that include syphilitic stillbirths are lacking, ${ }^{16}$ as it occurs in Mexico.

The comparison and contrast of national and international documents brings to light the need to update the standards with regard to the detailed and specific protocol for primary care, the follow-up of the woman, her sexual contacts and her children (including stillbirths), and new diagnostic tests, rapid tests and the reverse algorithm, in order to help eliminate syphilis mother-to-child transmission.

\section{Acknowledgements}

Part of this work was developed with the ISS-CONACyT-2015-262303 support.

\section{References}

1. Peeling RW, Mabey D, Kamb ML, Chen XS, Radolf JD, Benzaken AS Syphilis. Nat Rev Dis Primers. 2017;12;3:17073.

2. Berman SM. Maternal syphilis: pathophysiology and treatment. Maternal syphilis: pathophysiology and treatment. Bull World Health Organ. 2004;82:433-438

3. PAHO. Elimination of mother-to-child transmission of HIV and syphilis: update 2015. Washington. EE. UU.: PAHO; 2015.

4. Secretaría de Salud [sitio web]. Anuarios de morbilidad 1984-20175 Disponible en: https://www.gob.mx/salud/acciones-y-programas/anuarios-de-morbilidad-1984-2017.

5. Conde-González CJ, Valdespino JL, Juárez Figueroa LA, Palma O-. Olamendi-Portugal M, Olaiz-Fernández G, et al. Prevalencia de anticuerpos antitreponémicos y características sociodemográficas de la pobłación mexicana adulta en el año 2000. Salud Publica Mex. 2007;49:S412-\$420.

6. Yáñez-Álvarez I, Conde-González CJ, Uribe-Salas FJ, Olamendi-Portugal ML, García-Cisneros S, Sánchez-Alemán MA. Maternal/child seroprevalence of antibodies against Treponema pallidum at four generalhospitals in the state of Morelos, Mexico. Arch Med Res. 2012;43:571-577.

7. Noyola DE, Malacara-Alfaro O, Lima-Rogel V, Torres-Montes A. Seroprevalencia de sífilis en mujeres embarazadas en San Luis Potosí.Salud Publica Mex. 2006:48:151-154.

8. Zamilpa-Mejía LG, Uribe-Salas F, Juárez-Figueroa L, Calderón-Jaimes E, Conde-González CJ. Prevalencia y factores asociados consífilis y herpes genital en dos grupos de población femenina. Salud Pưblica Mex. 2003;45:S617-S623.

9. Juárez-Figueroa LA, Meléndez-Betancourt LA, Conde-González C. llazgo de sífilis a término del embarazo en mujeres de Cuernavaca $M o r$. Rev Invest Clin. 2001;53:375-377.

10. Organización Panamericana de la Salud. Iniciativa regional para ta eliminación de la transmisión maternoinfantil de VIH y de la sífilis côngénita en América Latina y el Caribe. Documento conceptual. Urüguay: Centro Latinoamericano de Perinatología/Salud de la Mujer y Reproductiva/Organización Panamericana de la Salud/Organización MundiąPde la Salud; 2009.

11. Organización Panamericana de la Salud. ETMI-plus: marco para la eliminación de la transmisión maternoinfantil del VIH, la sífilis, la hepatitis y la enfermedad de Chagas; Uruguay: Organización Panamericana de la Salud/Organización Mundial de la Salud; 2017.

12. Organización Panamericana de la Salud. Eliminación de la tranșinisión maternoinfantil del VIH y la sífilis en las Américas. Actualización 2016. EE. UU.: Organización Panamericana de la Salud; 2017.

13. Norma Oficial Mexicana NOM-007-SSA2-2016, para la atención đele la mujer durante el embarazo, parto y puerperio. México: Diario Oficial de la Federación; 2016.

14. Norma Oficial Mexicana NOM-039-SSA2-2014, para la prevención y control de las infecciones de transmisión sexual. México: Diario Oficial de la Federación; 2017. 
15. Norma Oficial Mexicana NOM-010-SSA2-2018, para la prevención y e control de la infección por virus de la inmunodeficiencia humana. México: Diario Oficial de la Federación; 2018

16. Norma Oficial Mexicana NOM-017-SSA2-2012, para la vigilancia epidemiológica. México: Diario Oficial de la Federación; 2013.

17. Norma Oficial Mexicana NOM-034-SSA2-2013, para la prevención y control de los defectos al nacimiento. México: Diario Oficial de la Federación; 2014.

18. Norma Oficial Mexicana NOM-039-SSA2-2014, para la prevención y control de las infecciones de transmisión sexual. México: Diario Oficial de la Federación; 2017.

19. Norma Oficial Mexicana NOM-046-SSA2-2005. Violencia familiar, sexual y contra las mujeres. Criterios para la prevención y atención. México: Diario Oficial de la Federación; 2009.

20. Norma Oficial Mexicana NOM-253-SSA1-2012, para la disposición de sangre humana y sus componentes con fines terapéuticos. México: Diario Oficial de la Federación; 2012

21. Guía de práctica clínica. Enfermedades de transmisión sexual en e adolescente y adulto que producen úlceras genitales: herpes, sífilis, chancroide, linfogranuloma venéreo y granuloma inguinal. México: Secretaría de Salud; 2009.

22. Diagnóstico, tratamiento y seguimiento de la sífilis congénita en el primero y segundo nivel de atención. México: Secretaría de Salud; 2011.

23. Workowski KA, Bolan G. Sexually Transmitted Diseases Treatment Guidelines, 2015. MMWR Recomm Rep. 2015;64:34-50.

24. Prevención, diagnóstico y tratamiento en el binomio madre-hijo con infección por el VIH. México: Secretaría de Salud; 2016.
25. Álvarez-Hernández G, Salazar-Arriola SA, Bocanegra-Luna C. Gula para el diagnóstico y manejo de la sífilis en el embarazo, y prevención de lassífilis congénita. México: Secretaría de Salud Pública del Estado de Sonora;2012.

26. Pan American Health Organization. Syphilis testing practices in the Americas region: results of the 2014 survey. EE. UU.: Pan American flealth Organization/World Health Organization; 2016.

27. Nielsen-Aage H, Reyn A. The Treponema pallidum immobilization test. Bull World Health Organ. 1956;14:263-263-288.

28. Gayet-Ageron A, Lautenschlager S, Nine B, Perneger TV, Combescure C. Sensitivity, specificity and likelihood ratios of PCR in the diagnosis of syphilis: a systematic review and meta-analysis. Sex Transm Infect. 2013;89:25 1256 .

29. Peeling RW, Ye H. Diagnostic tools for preventing and managing maternal and congenital syphilis: an overview. Bull World Health Ofgan. 2004;82:439-446.

30. National Center for HIV/AIDS, Viral Hepatitis, STD, and TB Prevention Annual Report. EE. UU.: Centers for Disease Control and Prevention; 2016.

31. Janier M, Hegyi V, Dupin N, Unemo M, Tiplica GS, Potočnik M,-et al. 2014 European guideline on the management of syphilis. J EurAdad Dermatol Venereol. 2014;28:1581-1593.

32. The Sexually Transmitted Diseases Diagnostics Initiative, SpeciafTProgramme for Research \& Training in Tropical Diseases. The use of rapid syphilis tests. Suiza: United Nations Children's Fund/United Nations Development Programme/World Bank/World Health Organization; 2006.

33. Gliddon HD, Peeling RW, Kamb ML, Toskin I, Wi TE, Taylor MM. Asystematic review and meta-analysis of studies evaluating the performance and operational characteristics of dual point-of-care tests for Hi $\mathrm{V}$ and syphilis. Sex Transm Infect. 2017;93:S3-S15. 